\title{
Sustainable regional development and provincial development planning: the case of Bolu
}

\author{
O. Özbek \\ Department of City and Regional Planning, Selcuk University, Turkey
}

\begin{abstract}
This paper aims at analysing the possibilities of a development strategy for the realization of sustainable spatial development in Bolu (as an important tourism centre and transit point of Northwestern Anatolia in Turkey) and the principles and limitations of the 2023 Provincial Development Plan of Bolu (BIGEP). In Bolu province, where the co-existence of nature protection areas, a rich flora and fauna and historical settlements has provided suitable conditions for the development of mass tourism facilities, the earthquakes in the Eastern Marmara and Duzce in 1999 accelerated the urbanization of agricultural lands for housing needs at the sub-regional level. Both the need for spatial and economic planning of the future development of urban and rural settlements and the priorities of pre-disaster planning in the provincial area made necessary the preparation of a sub-regional development plan in Bolu. The BIGEP plan comprising the economic and spatial development strategies of Bolu province for 2023 can be evaluated as an effort to reveal the sub-regional development dynamics under the heading of a "provincial development plan". However, the content of the BIGEP requires elaboration in terms of the priorities of sustainable development. The implementation scope of the plan as a region under constant threat from earthquakes means that the discussion of sustainability is far from being a priority. Here, the crucial questions are which priorities, emphases and contents do the policies on spatial and economic structure in a region under threat of earthquake have? Which natural contradictions exist for a strategy on making such a region the focus of economic development? And lastly, can provincial development planning be a planning level for sustainable development of the build environment?

Keywords: sustainable urban development, sub-regional planning, provincial development.
\end{abstract}




\section{Introduction}

The earthquakes in the Eastern Marmara and Duzce in 1999 added new dimensions to the urban and sub-regional spatial developments in Bolu as an important tourism centre and transit point of Northwestern Anatolia in Turkey. In the post-earthquake period, Bolu experienced a rapid urban sprawl motivated by low-density residential development. In this period, the central city continuously lost its urban population, the residential development orientated toward the surrounding rural ring of the city. This development presented important threats to the spatial structure of a city where the agricultural production mainly depends on the small-scale farming in limited agricultural areas. The existence of large nature protection areas of special plants and animal species in the region constituted an important obstacle for the homogenization of urban population between urban and rural settlements. While these spatial developments occurred at the urban level, the spatial organization and socioeconomic structure remained the same at the sub-regional level. This dual structure can be evaluated as an important motivation for the preparation of the 2023 Provincial Development Plan of Bolu (BIGEP) in 2004. However, there is a need for the elaboration and revision of the aims, targets, strategies and implementation tools in the development plan in terms of emphasizing priorities of sustainable development. In the BIGEP, sustainability is only included as an emphasis in the formulation of general spatial development strategy and the targets and implementation tools of the plan are mainly based on the priorities and necessities of an economic growth through the realization of a commercial and industrial development at a sub-regional level.

\section{Sustainability and regional development}

A harmonious integration of environmental protection and management priorities and economic and spatial development goals was well incorporated into recent work within regional economic development. In the last fifteen years, sustainable urban and regional development became joint agenda for an environmentally sound economic development in both developed and developing countries through milestones of global cooperative efforts like Agenda 21, Earth Summit, Earth Summit +5 and Johannesburg Summit (UN Department of Economic and Social Affairs [1]).

In Agenda 21, Rio Declaration on Environment and Development in 1992, "promoting human settlement development" was regarded as an important discussion area under the headings of human settlement management, sustainable land-use planning, sustainable energy and transports systems, human resource development and integrated provision of environmental infrastructure. In the declaration, "promoting human settlement planning and management in disaster-prone areas" can be evaluated as an important programme area to reveal how the development goals for human settlements, economic sectors and environmental resources must be reformulated to establish both "a culture of 
safety" and "pre-disaster planning" in urban and rural communities (UN Department of Economic and Social Affairs, Division of Sustainable Development [2]). The principles and implementation tools in this programme area of Agenda 21 is important whether regional economic and spatial development in these disaster-prone areas is sustained by a complete limitation of development vision of urban settlements at different scales or new environmentally sound and disaster-sensitive development dynamics. The selection of one of these two strategic ways mainly depends on a clear formulation of long-term economic and spatial development goals across a full range of spatial scales from national to local. Here, sub-regional planning can be taken as an intermediate planning level to provide a harmonious integration between national and regional economic development goals and local development strategies at provincial, urban and rural levels.

\section{Sustainable regional development and provincial development planning: the case of Bolu}

Bolu province is an important tourism centre and transit point of Northwestern Anatolia in Turkey locating on the most important highway of Northwestern Anatolia (Gerede-Yenicaga-Bolu) connecting capital city Ankara to Istanbul. As the North Anatolian fault line passes through the provincial area, Bolu is under constant threat of earthquake and whose urban and rural areas were negatively affected by the earthquakes in the Eastern Marmara and Duzce in 1999. The natural assets of Bolu province make this area more important regional, national and international tourism centre. The provincial area includes one national park, one nature park, five nature protection zones and two wildlife protection areas (see table 1).

Table 1: $\quad$ Selected nature protection areas in Bolu province [3].

\begin{tabular}{|l|l|c|l|}
\hline area class & \multicolumn{1}{|c|}{ name of area } & $\begin{array}{c}\text { size of } \\
\text { area (ha) }\end{array}$ & \multicolumn{1}{|c|}{ characteristics of area } \\
\hline national park & $\begin{array}{l}\text { Yedigoller } \\
\text { (Seven Lakes) }\end{array}$ & 2.019 & $\begin{array}{l}\text { rich forest eco-systems, flora, fauna } \\
\text { and recreational facilities }\end{array}$ \\
\hline $\begin{array}{l}\text { nature protection } \\
\text { zone }\end{array}$ & $\begin{array}{l}\text { Akdogan } \text { and } \\
\text { Ruzgarlar }\end{array}$ & 174 & $\begin{array}{l}\text { the world's only natural growing } \\
\text { area of Ebe pine (pinus nigra ssp. } \\
\text { pallasiana var. seneriana) }\end{array}$ \\
\hline $\begin{array}{l}\text { nature protection } \\
\text { zone }\end{array}$ & Demircionu & 430 & $\begin{array}{l}\text { pure and mixed communities of } \\
\text { beech (fagus sp.), hornbeam } \\
\text { (carpinus sp.), chestnut (castanea } \\
\text { sp.) and oak (quercus sp.) trees }\end{array}$ \\
\hline nature park & Abant Lake & 1.150 & $\begin{array}{l}\text { rich scenery, flora, fauna and } \\
\text { recreational facilities }\end{array}$ \\
\hline $\begin{array}{l}\text { wildlife protection } \\
\text { area }\end{array}$ & $\begin{array}{l}\text { Geyik Lake } \\
\text { (Deer Lake) in } \\
\text { Mengen district }\end{array}$ & 53.594 & protected wildlife areas of deers \\
\hline
\end{tabular}


According to the NUTS (Nomenclature of Territorial Units for Statistics) classification, the province takes place in the Eastern Marmara region (TR4) at NUTS 1 level and in the Kocaeli sub-region (TR42) at NUTS 2 level. As seen in fig. 1, Kocaeli sub-region, which comprises the provinces of Kocaeli, Sakarya, Duzce, Bolu and Yalova, had the highest value (\$4109) of per capita gross domestic product (GDP) at current prices in 2001 among other statistical subregions of Turkey. This highest GDP value of the sub-region may be explained by the fact that most of nationally strategic industrial and commercial establishments located along the industrial corridor of the Eastern Marmara near to Istanbul. At provincial level (NUTS 3), Bolu had the second highest per capita GDP value (\$4216) in comparison with other provinces in Turkey (T.R. Prime Ministry Turkish Statistical Institute [4]). However, this GDP value is not an indicator of real economic prosperity of the province because the huge construction costs of the Bolu Mountain tunnel (one of most costly and prolonged transportation projects of Turkey aimed at shortening the route between Istanbul and the capital city Ankara) artificially exaggerates the GDP value of the province.

Regional locational advantages, rich natural resources and economic development potential make Bolu province a candidate for an important tourism centre in the Kocaeli sub-region. However, both the seismic characteristics and nature protection priorities of the provincial area tend to constrain the possibilities of implementing a large-scale development strategy aiming to homogenize industrial/commercial development at sub-regional level and to create large agglomerations of urban settlements. At this point, 2023 Provincial Development Plan of Bolu for 2023, which was prepared in 2004, can be evaluated as an effort to determine how environmentally sound and disastersensitive development initiatives can be activated to sustain spatial and economic development in the area.

\subsection{Provincial development plan of Bolu (BIGEP)}

The vision of the Provincial Development Plan of Bolu (BIGEP) is based on a framework including the components of geographical location, sectoral structure and socio-cultural infrastructure: "an agricultural-industrial and social city which is sensitive to the priorities of natural environment, produces the high value added agricultural and industrial product and functions as a nature, health and sport centre" (T.R. Prime Ministry State Planning Organization et al [5]). This definition that claims to have a sustainability emphasis, however, has the emphasis on realizing both an economic growth and spatial development paralleling to this growth at sub-regional level. The basic principles of the BIGEP can be given as follows:

- To realize the sustainability of economic and social development.

- To realize the coordination between the provincial development plan and national development plan in terms of development policy.

- To develop institutional capacity and to provide the participation of public in both planning and implementation. 


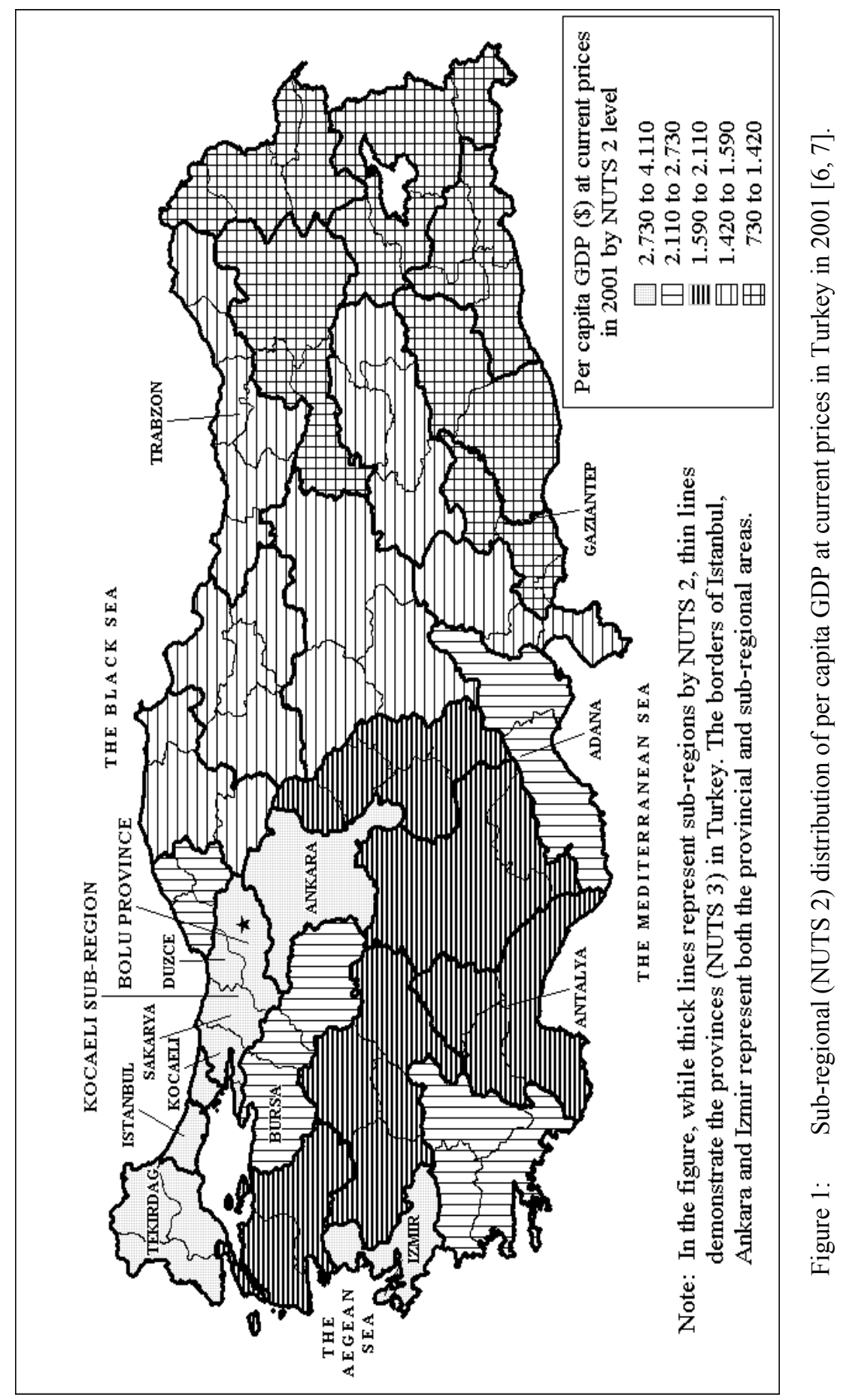


- To follow an investment policy based on the priorities of the private sector and to constitute an investment climate.

- To emphasize sustainability in both the supervision of urban growth and the realization of regional industrial development.

- To prepare an infrastructure for socio-economic development and to develop institutional capacity in the rural areas.

- To emphasize the importance of human resources development in the policies for both population mobility and homogenisation of regional development (T.R. Prime Ministry State Planning Organization et al [5]).

In the determination of the strategies of the BIGEP that has a twenty-year horizon (2003-2023), the national and regional development goals and strategies in the Eighth Five Years Development Plan of Turkey (2001-2005) are worthy of note. These strategies aimed at utilizing the potentials in tourism and agriculture can be given as follows:

- To establish a harmony of urban, land use and environmental adjustment plans by taking with a focus on earthquake and other physical factors.

- To prevent urbanization of fertile agricultural lands and to determine new areas for different land uses.

- To locate industrial activities in the industrial complex outside the province.

- To promote agricultural production with a high market value at technical support of TUBITAK (The Scientific \& Technological Research Council of Turkey) and to realize crop diversification in the agricultural sector.

- To encourage land consolidation for providing the productivity in agricultural production, to protect the soil resources and to encourage contractual production in agriculture.

- To implement pilot projects on organic agricultural production and to improve the infrastructure of agriculture and stockbreeding.

- To implement small-scale rural development projects for preventing immigration in underdeveloped rural areas.

- To improve productivity, institutional infrastructure and interaction among firms in the industrial sector.

- To improve the entrepreneurial capacity of small and medium-scale firms.

- To improve both existing and alternative tourism types and to diversify the supply of touristic products.

- To execute an effective activity program for the promotion of tourism values.

- To prepare educational programs in terms of increasing knowledge and abilities of unskilled labour.

- To take measures to develop the human and physical infrastructure of education.

- To improve both the infrastructure and accessibility of health services at urban and rural levels.

- To improve the institutional capacity of public and social service institutions.

- To form a city council functioning in both the coordination among different administrative actors and the development of administrative capacity at rural level.

- To provide an effective use of geographic information systems. 
- To improve the infrastructure of transportation and telecommunications in terms of both strengthening relationships between rural and urban settlements and accessing the market (T.R. Prime Ministry State Planning Organization et al [5]).

The principles, targets and strategies of the BIGEP summed up above incorporated together to the development scenarios for 2023 in terms of making realistic predictions about the sub-regional economic and spatial development in the future. In the projection of existing trends for the year 2023, three different development scenarios defined a spatio-temporal framework: a continuation of existing economic and spatial conditions and stable growth, a growth dependent on local resources in support of public sector and a sustainable development both with the strong support of public sector and under the leadership of private sector. The first scenario suggests a stable regional economic development in which idle economic resources will be put into efficient use and there will no longer be an external intervention in sub-regional economic growth. In this scenario, the continuation of migration pressures toward urban centres is emphasized as a result of an anticipated failure of struggles for the vitalization of rural economy. The second scenario indicates a development trajectory in which a local resource and agriculture-centric regional development will be achieved through public and private sector resource allocation paralleling to the improvement of institutional capacity. The third scenario includes a more realistic economic growth through the realization of sustainable development with both technical and financial support of European Union and the reform of the fiscal system and public administration in Turkey. However, in this scenario, the anticipated positive developments like "an improvement in rural industry, an increase in the occupancy rate of touristic facilities, a creation of an investment climate and vitalization of the commercial sector" can be evaluated as the developments toward realizing a high growth rate at provincial level instead of having an emphasis on sustainability (T.R. Prime Ministry State Planning Organization et al [5]).

Some of the foresights of the BIGEP reveal possible negative outcomes of sub-regional developments in the triangle of economic structure, build environment and earthquake sensitivity. In the foresights for 2010, it is drawn attention that rapid population growth can encourage further urban sprawl in Bolu province (Özbek [8]). First, a rapid population growth in the corridor of Gerede-Yenicaga-Bolu is likely to cause critical environmental and residential development problems. Second, approximately 5000 hectares of arable land in the Bolu plain will be allocated for housing purposes since safe residential areas by earthquake are so limited in the province. The foresights for 2020 indicates that the scope and speed of urban sprawl toward agricultural areas in the province will increase unless new development strategies of the BIGEP will be adopted by local and central authorities responsible for build environment. In 2020 , it is anticipated that some of existing rural and urban settlements will become large urban agglomerations in the development corridor of GeredeYenicaga-Bolu and the extent of urbanized agricultural lands will go up by 15000 hectares (T.R. Prime Ministry State Planning Organization et al [3]). The 
anticipations for 2010 and 2020 point out that urban sprawl as an inevitable process will radically alter both the settlement structure and the spatial composition of rural an urban activities in Bolu province. Here, with the BIGEP initiatives, it is aimed to slow down the pace of urbanization and to lessen the negative effects of sub-regional spatial development motivated by low-density housing in the province under constant threat of earthquake.

\subsection{A critique of the BIGEP for sustainable regional development}

A critique of socio-economic, spatial and ecological initiatives of the BIGEP is necessary to comprehend the potential problems in the conceptualisation of a new level or type of regional planning (provincial development planning) in Turkey. Here, a crucial question highlights necessity for a revision of regional development goals and priorities of responsible central and local planning authorities: Can provincial development planning be a planning level for sustainable development of build environment? The case of Bolu also reveals additional questions to be answered in terms of producing realistic and powerful foresight strategies at sub-regional level: Which priorities, emphases and contents do the policies on spatial and economic structure in a region under threat of earthquake have? Which natural contradictions do exist for a strategy on making such a region focus of economic development?

In Bolu province, where the co-existence of nature protection areas, a rich flora and fauna, historical settlements has provided suitable conditions for the development of mass tourism facilities, the provincial development strategies of the BIGEP depending on the priorities of agricultural, commercial and industrial sectors are likely to accelerate the urbanization of agricultural lands at subregional level. With the development strategies of the BIGEP, sub-regional and urban housing development in the area, which was led by the needs of population and threats of earthquake in the past, will be motivated by new sectoral growth dynamics. In this possible development scenario, the BIGEP assigns important administrative, commercial and industrial functions to the central city of Bolu and these central functions are possible to make the spatial and economic development in the corridor of Gerede-Yenicaga-Bolu cumulative and to cause the emergence of new sub-centers along this corridor (Özbek [8]).

A close inspection of table 2 indicates that the development principles and implementation tools of the BIGEP must be reformulated to combat the anticipated negative effects of both urban sprawl and sub-regional economic development in Bolu province. Here, there is an urgent need to establish goal consistency between different spatial scales in terms of rural development, settlement strategies and long-term regional plans. The threats of earthquake and nature protection issues must be incorporated into the development scenarios at each spatial scale. In addition, the limited success and implementation scope of environmental adjustment and land use plans in Turkey makes necessary the adoption of sub-regional planning as a new and main planning level in the BIGEP. 
Table 2: $\quad$ Selected development initiatives and implementation tools for the BIGEP at different spatial scales.

\begin{tabular}{|c|c|c|}
\hline & development principles & implementation tools \\
\hline rural level & $\begin{array}{l}\text { - development of agricultural industry } \\
\text { - } \quad \text { diversification of agricultural } \\
\text { products } \\
\text { prevention of urbanization of fertile } \\
\text { agricultural lands } \\
\text { Problem: How will rural development } \\
\text { initiatives on rural settlements and rural } \\
\text { environment be realized in an area of } \\
\text { rapid urbanization? }\end{array}$ & $\begin{array}{ll}\text { - } & \text { small-scale rural } \\
& \text { development schemes } \\
\text { - } & \text { new environmental } \\
& \text { adjustment plans } \\
\text { - } & \text { industrial } \\
& \text { decentralization } \\
\text { - } & \text { agricultural projects of } \\
& \text { TUBITAK } \\
\text { - } & \text { land consolidation } \\
\text { - contractual agricultural } \\
\text { production } \\
\text { pilot projects on organic } \\
\text { agriculture }\end{array}$ \\
\hline $\begin{array}{l}\text { urban } \\
\text { level }\end{array}$ & $\begin{array}{l}\text { - establishment of a harmony between } \\
\text { land use and environmental } \\
\text { adjustment plans in terms of the } \\
\text { priorities of disaster-sensitive } \\
\text { planning } \\
\text { allocation of new urban areas for } \\
\text { different land uses } \\
\text { Problem: How will environmentally } \\
\text { sound new settlement strategies be } \\
\text { produced under constant threats of } \\
\text { earthquake and urban sprawl? }\end{array}$ & $\begin{array}{ll}\text { - } & \text { new environmental } \\
& \text { adjustment plans } \\
\text { - } & \text { new urban land use plans } \\
\text { - } & \text { new administrative body } \\
\text { (city council) } \\
\text { - } \\
\text { geographic information } \\
\text { systems }\end{array}$ \\
\hline $\begin{array}{l}\text { provincial } \\
\text { level }\end{array}$ & 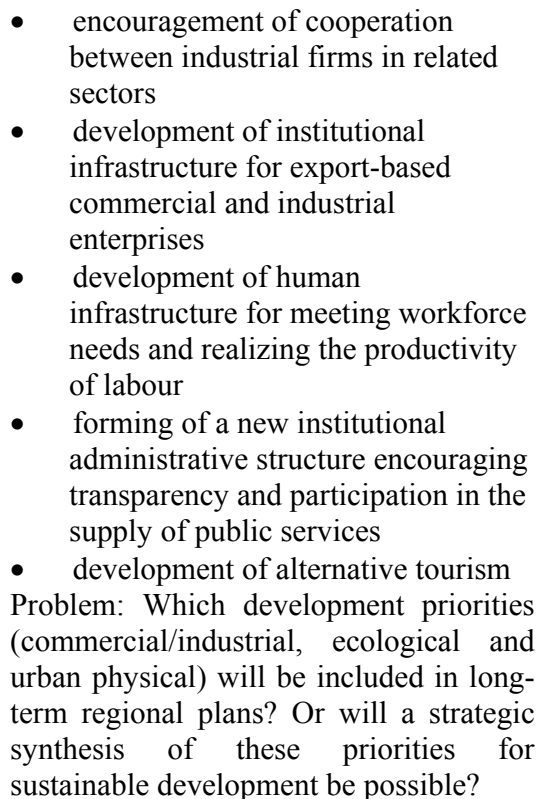 & $\begin{array}{ll}\text { - } & \text { BIGEP initiatives } \\
& \text { new environmental } \\
\text { - } & \text { adjustment plans } \\
& \text { touristic activity } \\
& \text { programs } \\
\text { - } & \text { training programs for } \\
& \text { workforce } \\
\text { - } & \text { new administrative body } \\
& \text { (city council) } \\
\text { geographic information } \\
\text { systems }\end{array}$ \\
\hline
\end{tabular}




\section{Conclusion}

An analysis and critique of the BIGEP initiatives and development principles provide important insights for how a decision framework for sustainable development can be incorporated into a new level of spatial planning (provincial development planning). The case of Bolu indicates that a harmonious integration of regional development and environmental protection goals is predominantly important to limit the future development of urban settlements in disaster-prone areas. In the same vein, there is a need to revise the principles, goals and implementation tools of the BIGEP. In the provincial development plan, the content of goals and targets for rural development, development of institutional capacity and human infrastructure, homogenisation of spatial development at sub-regional level and industrial/commercial development require elaboration in terms of the priorities of sustainable development. Here, rather than including as physical factors or emphasises in the BIGEP, the issues of nature protection and threats of earthquake need to be addressed as the main policy determinants within the regional economic and spatial development framework.

\section{References}

[1] UN Department of Economic and Social Affairs. Division of Sustainable Development Web Site, New York, www.un.org/esa/sustdev.

[2] UN Department of Economic and Social Affairs, Division of Sustainable Development. Agenda 21. www.un.org/esa/sustdev/documents/agenda21 lenglish/agenda21 toc.htm.

[3] T.R. Prime Ministry State Planning Organization, T.R. Governorship of Bolu, The Bolu Municipality, The University of Abant Izzet Baysal \& The Bolu Chamber of Commerce and Industry, Bolu Provincial Development Plan: Environment and Spatial Structure, 2004.

[4] T.R. Prime Ministry Turkish Statistical Institute. Per Capita GDP at Current Prices in 2001 by NUTS 3, Ankara, Turkey, www.die.gov.tr /nuts/131d3.xls.

[5] T.R. Prime Ministry State Planning Organization, T.R. Governorship of Bolu, The Bolu Municipality, The University of Abant Izzet Baysal \& The Bolu Chamber of Commerce and Industry, Bolu Provincial Development Plan (BIGEP): Master Plan, 2004.

[6] T.R. Prime Ministry Turkish Statistical Institute. Classification of Territorial Units for Statistics, Ankara, Turkey, www.die.gov.tr /nuts/bolgekarar.htm.

[7] T.R. Prime Ministry Turkish Statistical Institute. Per Capita GDP at Current Prices in 2001 by NUTS 2, Ankara, Turkey, www.die.gov.tr/duzey2/131d2.xls.

[8] Özbek, O., Sub-regional development strategies and sensitivity to earthquake: An analysis of the Bolu provincial development plan. The $29^{\text {th }}$ Colloquium of World Urbanism Day, 7-9 November, Istanbul Technical University, Faculty of Architecture, Istanbul, pp. 107-117, 2005. 